\title{
Identification of key transcription factors - gene regulatory network related with osteogenic differentiation of human mesenchymal stem cells based on transcription factor prognosis system
}

\author{
XUEFENG KANG, YONG SUN and ZHAO ZHANG \\ Department of Orthopedics, Heilongjiang Provincial Hospital, Harbin, Heilongjiang 150030, P.R. China
}

Received June 4, 2018; Accepted January 10, 2019

DOI: $10.3892 /$ etm.2019.7170

\begin{abstract}
Human mesenchymal stem cells (hMSCs) have the capacity to differentiate into fabricate cartilage, muscle, marrow stroma, tendon/ligament, fat, and other connective tissues, providing a potential source for tissue regeneration. The aim of this study was to find the key transcription factors (TFs), which regulated osteogenic differentiation of hMSCs. In this study, three methods were performed to find the key TFs, which included enrichment analysis, direct impact value and indirect impact value. We used the patient and public involvements (PPI) network to integrate the results of the above methods for analysis. Then, we compared the osteoblast data to the control group on days 1,3 and 7. Finally, we found the combination of the optimal and vital 30 TFs related to osteogenic differentiation. TFs FOS, SOX9 and EP300 were commonly expressed in 3 different days in the osteogenic lineages and presented in the PPI network at relatively high degrees. Moreover, TFs CREBBP, ESR1 and EGR1 also presented high effects on the 1 st, 3rd and 7th day. The constructed network gives us a more comprehensive understanding of the mechanism of osteogenesis of hMSCs.
\end{abstract}

\section{Introduction}

Osteoporosis, which primarily affects older women, is defined as a systemic skeletal disease characterized by low bone mass, and deterioration of bone tissue $(1,2)$. The occurrence of osteoporosis is mainly caused by micro-architectural deterioration of bone tissues, which leads to decreased skeletal strength and increased susceptibility to fractures. Human mesenchymal stem cells (hMSCs) have the capacity to differentiate into fabricate cartilage, muscle, marrow stroma, tendon/ligament,

Correspondence to: Dr Zhao Zhang, Department of Orthopedics, Heilongjiang Provincial Hospital, 82 Zhongshan Road, Xiangfang, Harbin, Heilongjiang 150030, P.R. China

E-mail: 13613661186@163.com

Key words: osteogenic capacity, TF, transcription factor prognosis system, LIMMA, Fish enrichment fat, and other connective tissues, providing a potential source for tissue regeneration $(3,4)$. It has shown that hMSCs could enhance bone regeneration and repair in animal models for bone regeneration as well as in clinical practice.

Normally, osteoclast cells resorb bone in bone marrow and deposit new bone by osteoblast. Recently, it was reported that the key TFs play significant roles in osteogenesis through binding with cis-regulatory elements to control expression levels of downstream genes (5). The proliferation and differentiation of osteoblasts are regulated by many TFs including the HLH protein family members, leucine zipper protein, zinc finger protein and ischemic zone protein (6). Furthermore, Harada et al (7) have found that Cbfa1 and OSF2 were essential TFs for osteoblast differentiation and bone formation. In addition, Hanai et al (8) demonstrated that Cbfa1 and other molecules form complexes that interact closely during osteoblast differentiation. Moreover, these observations indicated Cbfal is not a sufficient TF for osteoblast differentiation. The studies suggested that osteogenesis was achieved under the combined regulation of multiple TFs and many limitations existed to studying a single TF. Therefore, it may be more conducive to understanding the mechanism of osteogenesis that multiple TFs were integrated to observe their combined effects on osteogenesis.

Thus, we proposed a TF prognosis system (TFpro), which combined the regulatory network of gene expression data to predict key and essential TFs that induced cell transformation. In the present study, LIMMA was used for identifying the different expression gene taken from Array Express dataset. Next, the Fish enrichment analysis was used for identifying the TFs which targeted differential expression genes. Then, we calculated a TF gene-based and net-based sphere of influence and ranked the TFs on the basis of the above results. Finally, we obtained the key TFs of osteogenesis.

\section{Materials and methods}

Data source and data preprocessing. The profile E-GEOD-18043 (http://www.genelibs.com/gen/command/ search/ experiment/detail/58610) was downloaded from Array Express serving as a public genetic chip database. In the original research, 12 samples were selected for analysis, including 
Table I. The information of 3 control samples.

\begin{tabular}{|c|c|c|c|c|c|c|c|c|}
\hline \multirow{2}{*}{$\begin{array}{l}\text { Sample } \\
\text { number }\end{array}$} & \multirow[b]{2}{*}{ Title } & \multirow{2}{*}{$\begin{array}{l}\text { Sample } \\
\text { type }\end{array}$} & \multicolumn{4}{|c|}{ Characteristics } & \multirow{2}{*}{$\begin{array}{c}\text { Extraction } \\
\text { protocol }\end{array}$} & \multirow[b]{2}{*}{ Label } \\
\hline & & & Cell type & Sex & Age & Treatment & & \\
\hline GSM250019 & $\begin{array}{l}\text { BM-MSC } \\
\text { culture rep } 1\end{array}$ & RNA & $\begin{array}{l}\text { Bone } \\
\text { marrow-derived } \\
\text { mesenchymal } \\
\text { stem cells }\end{array}$ & Male & 67 years & None & $\begin{array}{l}\text { RNA was } \\
\text { collected using } \\
\text { the RNeasy } \\
\text { mini kit } \\
\text { (Qiagen) }\end{array}$ & Biotin \\
\hline GSM250020 & $\begin{array}{l}\text { BM-MSC } \\
\text { culture rep } 2\end{array}$ & RNA & $\begin{array}{l}\text { Bone } \\
\text { marrow-derived } \\
\text { mesenchymal } \\
\text { stem cells }\end{array}$ & Male & 72 years & None & $\begin{array}{l}\text { RNA was } \\
\text { collected using } \\
\text { the RNeasy } \\
\text { mini kit } \\
\text { (Qiagen) }\end{array}$ & Biotin \\
\hline GSM250021 & $\begin{array}{l}\text { BM-MSC } \\
\text { culture rep } 3\end{array}$ & RNA & $\begin{array}{l}\text { Bone } \\
\text { marrow-derived } \\
\text { mesenchymal } \\
\text { stem cells }\end{array}$ & Female & 74 years & None & $\begin{array}{l}\text { RNA was } \\
\text { collected using } \\
\text { the RNeasy } \\
\text { mini kit } \\
\text { (Qiagen) }\end{array}$ & Biotin \\
\hline
\end{tabular}

3 control samples (Table I) and 9 experimental samples (Table II), and the latter included gene expression profiles generated by hMSCs after the 1st, 3rd and 7th day of dexamethasone stimulation (3 samples, respectively). Operationally, we converted the expression profile from probe level to gene symbol level and removed duplicate symbols. Finally, the expression data of 20,514 genes were captured.

Screening for DEGs. LIMMA package (5) was used to calculate the differential expression of genes from the 9 experimental samples and 3 control samples to screen for DEGs. If the number of DEGs was $<300$, the difference between the screening expression value of the first 300 would be DEGs. LIMMA performed t-test and F-test on the gene expression matrix, the lmFit function was used for linear fitting, eBayes statistics, and FDR-corrected P-values $(\leq 0.05)$.

Gene set enrichment analysis. Each TF has corresponding regulatory genes. If these regulatory genes are coincidentally included in these DEGs, then, their TFs may have a regulatory effect on osteogenesis. Therefore, it is necessary to carry out enrichment analyses of these differentially expressed genes to see if there are still some potential TFs which have a regulatory effect on osteogenesis. In view of this, Fisher's test (9) was used to identify enriched TFs in our study. In detail, Fisher's test was used to determine if the two overall ratios are equal. That is, the random ratio is equal to the experimental ratio. The null hypothesis assumed that the two population ratios were equal $(\mathrm{H} 0$ : $\mathrm{p} 1=\mathrm{p} 2)$; alternative hypotheses might be lefttailed (p1 <p2), right tail $(\mathrm{p} 1>\mathrm{p} 2)$, or two-tailed $(\mathrm{p} 1 \neq \mathrm{p} 2)$.

\section{The impact factor of TFs}

Direct influence value of TFs. TFs with a high level of influence were determined through a formula, in which the fold changes expressed in logarithmic transformation and the FDR adjusted P-value was converted to individual gene scores. The analytical formula is as follows:

$$
\mathrm{G}_{\mathrm{xs}}=\left|\mathrm{Lxs}_{\mathrm{xs}}\right|\left(-\log _{10} \mathrm{P}_{\mathrm{xs}}\right)
$$

In this formula, $\mathrm{L}$ is the difference $\log \mathrm{FC}$ value of the relevant genes, and the P-value is the difference P-value calculated by LIMMA. This formula showed the changes of the target gene for each TF. If a TF regulated many genes these genes had large changes, the gene's $G$ score would be higher. Thus, using this method allowed finding the more common TFs. Furthermore, when comparing the $\mathrm{G}$ score, the average $\mathrm{G}$ score, and the number of genes, we could obtain a rank score, the lower scores indicating that the impact of this gene was greater in the comprehensive consideration.

Indirect network influence value of TFs. TFs could not only affect the expression of changes, but also co-expression with their target genes. Thus, in order to assess the importance of each TF co-expressed in the network, we used STRING database and TF library (TF library from the above three databases) to calculate the impact of TFs on the local area. TF library, which represents a low-level, targeted regulatory interaction network, provides protein-DNA interactions for TFs with known binding sites in the promoter region of the genes. On the other hand, STRING, which provides a view that directly and indirectly affects the interaction of gene expression, is an interactive metadata library that contains various interactions of protein-protein, protein-DNA and protein-RNA interactions and biological pathways (5). The final STRING correlation value was obtained by multiplying the Pearson's correlation coefficient between the STRING database score and the actual data. We performed a weighted sum of the genetic effects on the local network neighborhoods of TFs. Moreover, the correlation coefficient between the TF 
Table II. The information of 9 experiment samples.

\begin{tabular}{|c|c|c|c|c|c|c|c|c|c|}
\hline \multirow[b]{2}{*}{$\begin{array}{l}\text { Sample } \\
\text { number }\end{array}$} & \multirow[b]{2}{*}{ Title } & \multirow[b]{2}{*}{$\begin{array}{l}\text { Sample } \\
\text { type }\end{array}$} & \multicolumn{5}{|c|}{ Characteristics } & \multirow[b]{2}{*}{$\begin{array}{c}\text { Extraction } \\
\text { protocol }\end{array}$} & \multirow[b]{2}{*}{ Label } \\
\hline & & & cell type & Sex & Age & Treatment & $\begin{array}{l}\text { Treatment } \\
\text { time }\end{array}$ & & \\
\hline GSM451153 & $\begin{array}{l}\text { BM-MSC } \\
\text { culture } \\
\text { osteogenic } \\
\text { induction } \\
\text { for } 1 \text { day } \\
\text { rep } 1\end{array}$ & RNA & $\begin{array}{l}\text { Bone } \\
\text { marrow- } \\
\text { derived } \\
\text { mesenchymal } \\
\text { stem cells }\end{array}$ & Male & 67 years & Dexamethasone & 1 day & $\begin{array}{l}\text { RNA was } \\
\text { collected } \\
\text { using the } \\
\text { RNeasy } \\
\text { mini kit } \\
\text { (Qiagen). }\end{array}$ & Biotin \\
\hline GSM451154 & $\begin{array}{l}\text { BM-MSC } \\
\text { culture } \\
\text { osteogenic } \\
\text { induction } \\
\text { for } 1 \text { day } \\
\text { rep } 2\end{array}$ & RNA & $\begin{array}{l}\text { Bone } \\
\text { marrow- } \\
\text { derived } \\
\text { mesenchymal } \\
\text { stem cells }\end{array}$ & Male & 72 years & Dexamethasone & 1 day & $\begin{array}{l}\text { RNA was } \\
\text { collected } \\
\text { using the } \\
\text { RNeasy } \\
\text { mini kit } \\
\text { (Qiagen). }\end{array}$ & Biotin \\
\hline GSM451155 & $\begin{array}{l}\text { BM-MSC } \\
\text { culture } \\
\text { osteogenic } \\
\text { induction } \\
\text { for } 1 \text { day } \\
\text { rep } 3\end{array}$ & RNA & $\begin{array}{l}\text { Bone } \\
\text { marrow- } \\
\text { derived } \\
\text { mesenchymal } \\
\text { stem cells }\end{array}$ & Female & 74 years & Dexamethasone & 1 day & $\begin{array}{l}\text { RNA was } \\
\text { collected } \\
\text { using the } \\
\text { RNeasy } \\
\text { mini kit } \\
\text { (Qiagen). }\end{array}$ & Biotin \\
\hline GSM451156 & $\begin{array}{l}\text { BM-MSC } \\
\text { culture } \\
\text { osteogenic } \\
\text { induction } \\
\text { for } 3 \text { day } \\
\text { rep } 1\end{array}$ & RNA & $\begin{array}{l}\text { Bone } \\
\text { marrow- } \\
\text { derived } \\
\text { mesenchymal } \\
\text { stem cells }\end{array}$ & Male & 67 years & Dexamethasone & 3 days & $\begin{array}{l}\text { RNA was } \\
\text { collected } \\
\text { using the } \\
\text { RNeasy } \\
\text { mini kit } \\
\text { (Qiagen). }\end{array}$ & Biotin \\
\hline GSM451157 & $\begin{array}{l}\text { BM-MSC } \\
\text { culture } \\
\text { osteogenic } \\
\text { induction } \\
\text { for } 3 \text { day } \\
\text { rep } 2\end{array}$ & RNA & $\begin{array}{l}\text { Bone } \\
\text { marrow- } \\
\text { derived } \\
\text { mesenchymal } \\
\text { stem cells }\end{array}$ & Male & 72 years & Dexamethasone & 3 days & $\begin{array}{l}\text { RNA was } \\
\text { collected } \\
\text { using the } \\
\text { RNeasy } \\
\text { mini kit } \\
\text { (Qiagen). }\end{array}$ & Biotin \\
\hline GSM451158 & $\begin{array}{l}\text { BM-MSC } \\
\text { culture } \\
\text { osteogenic } \\
\text { induction } \\
\text { for } 3 \text { day } \\
\text { rep } 3\end{array}$ & RNA & $\begin{array}{l}\text { bone } \\
\text { marrow- } \\
\text { derived } \\
\text { mesenchymal } \\
\text { stem cells }\end{array}$ & Female & 74 years & Dexamethasone & 3 days & $\begin{array}{l}\text { RNA was } \\
\text { collected } \\
\text { using the } \\
\text { RNeasy } \\
\text { mini kit } \\
\text { (Qiagen). }\end{array}$ & Biotin \\
\hline GSM451159 & $\begin{array}{l}\text { BM-MSC } \\
\text { culture } \\
\text { osteogenic } \\
\text { induction } \\
\text { for } 7 \text { day } \\
\text { rep } 1\end{array}$ & RNA & $\begin{array}{l}\text { Bone } \\
\text { marrow- } \\
\text { derived } \\
\text { mesenchymal } \\
\text { stem cells }\end{array}$ & Male & 67 years & Dexamethasone & 7 days & $\begin{array}{l}\text { RNA was } \\
\text { collected } \\
\text { using the } \\
\text { RNeasy } \\
\text { mini kit } \\
\text { (Qiagen). }\end{array}$ & Biotin \\
\hline GSM451160 & $\begin{array}{l}\text { BM-MSC } \\
\text { culture } \\
\text { osteogenic } \\
\text { induction } \\
\text { for } 7 \text { day } \\
\text { rep } 2\end{array}$ & RNA & $\begin{array}{l}\text { Bone } \\
\text { marrow- } \\
\text { derived } \\
\text { mesenchymal } \\
\text { stem cells }\end{array}$ & Male & 72 years & Dexamethasone & 7 days & $\begin{array}{l}\text { RNA was } \\
\text { collected } \\
\text { using the } \\
\text { RNeasy } \\
\text { mini kit } \\
\text { (Qiagen). }\end{array}$ & Biotin \\
\hline GSM451161 & $\begin{array}{l}\text { BM-MSC } \\
\text { culture } \\
\text { osteogenic } \\
\text { induction } \\
\text { for } 7 \text { day } \\
\text { rep } 3\end{array}$ & RNA & $\begin{array}{l}\text { Bone } \\
\text { marrow- } \\
\text { derived } \\
\text { mesenchymal } \\
\text { stem cells }\end{array}$ & Female & 74 years & Dexamethasone & 7 days & $\begin{array}{l}\text { RNA was } \\
\text { collected } \\
\text { using the } \\
\text { RNeasy } \\
\text { mini kit } \\
\text { (Qiagen). }\end{array}$ & Biotin \\
\hline
\end{tabular}


A


Top 10 DEG
B
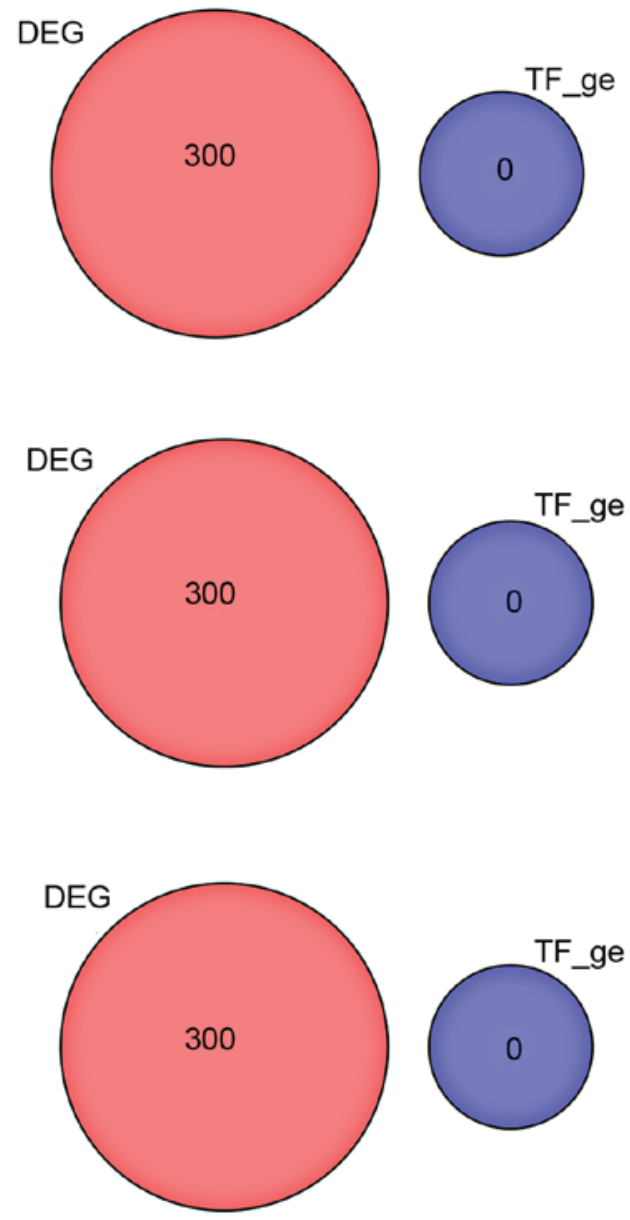

Venn diagram for the DE TF target gene in DEG

Figure 1. The enrichment analysis of osteogenic differentiation in differentially expressed genes. (A) The top 10 TFs logFC at day 1,3 and 7 , respectively. The abscissa is the top 10 differentially expressed genes. The ordinate is I log FC I for these 10 genes, respectively. The blue represents the log FC values of these genes are negative, and the red values of these genes are positive. (B) Venn diagram for the DE TF target in DEGs at day 1, 3 and 7, respectively.

and the target gene is obtained by STRING database scores or TF database scores as the following formulas:

$$
\begin{aligned}
& \text { TFCors,r=StringDatabaseCor(s,r) } \\
& \text { or TFCors,r=TFDatabaseCor(s,r) }
\end{aligned}
$$

TF database score was calculated as the formula:

$$
\text { TFDatabaseCor }(\mathrm{s}, \mathrm{r})=0.7+\mathrm{N} * 0.1
$$

( $\mathrm{N}$ is the number of records of the interaction between the $\mathrm{s}$ and $r$ genes of the database, the value of $0-1$ ). The formulas for performing this weighted sum were as follows:

$$
N_{x, n}^{s}=\sum_{r \in V_{x}}^{s} P_{s, r} \cdot G_{r}^{s} \cdot \frac{1}{L_{r, n}} \cdot \frac{1}{O_{r, n}}
$$

In this formula, Ns $\mathrm{x}, \mathrm{n}$ was weighted sum of TFs, $\mathrm{P}_{\mathrm{s}, \mathrm{r}}$ was the correlation coefficient between the TF and the affected genes, $\mathrm{L}_{\mathrm{r}, \mathrm{n}}$ represented the distance between the gene and the $\mathrm{TF}, \mathrm{O}_{\mathrm{r}, \mathrm{n}}$ represented the connectivity of the parent node.
It should be noted that $\mathrm{P}_{\mathrm{s}, \mathrm{r}}$ was calculated by the following formula:

$$
\text { Ps,r=TFCor(s,r)*Pearson(s,r) }
$$

Construction of protein-protein interaction (PPI) networks. In the network of interactions between proteins, gene functions also show some form of correlation (10). At this stage, PPI networks were used to observe the gene pairs between the two differently expressed groups. Firstly, we calculated the co-expression of two genes in the control groups as well as the co-expression of two genes in the experimental groups. Next, the differences between the co-expression values of the two genes in the two groups were calculated and the differences were taken as an absolute value. Finally, we multiplied this value with the background value and corrected it.

\section{Results}

The acquisition of DEGs. We extracted the genes that met the following conditions in the tested linear model: $|\log F C| \geq 2$ 

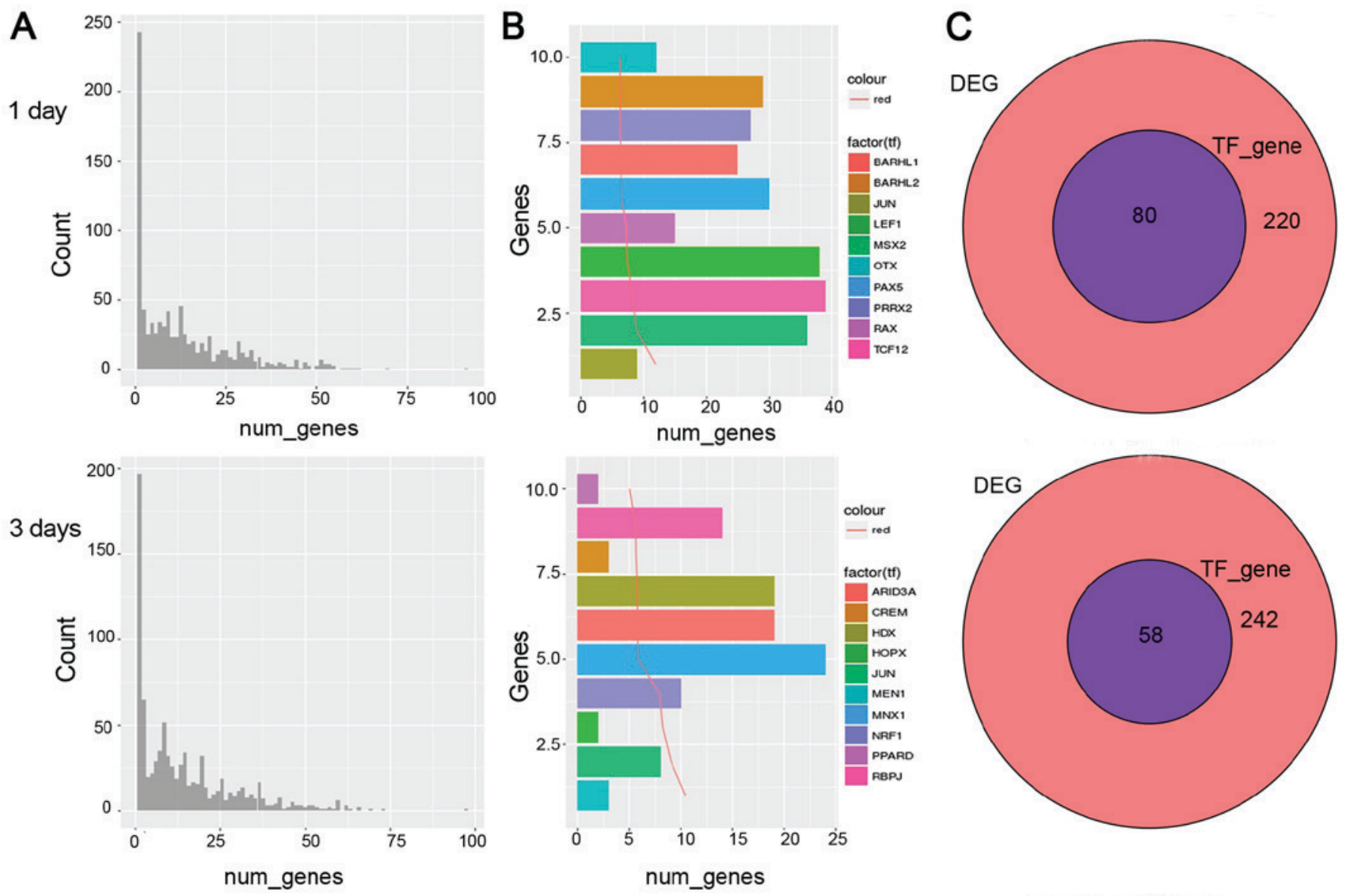

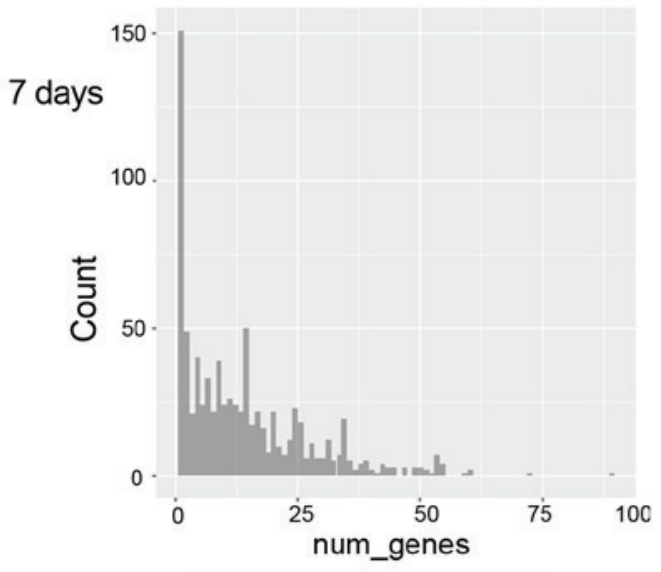

Enriched TF target genes

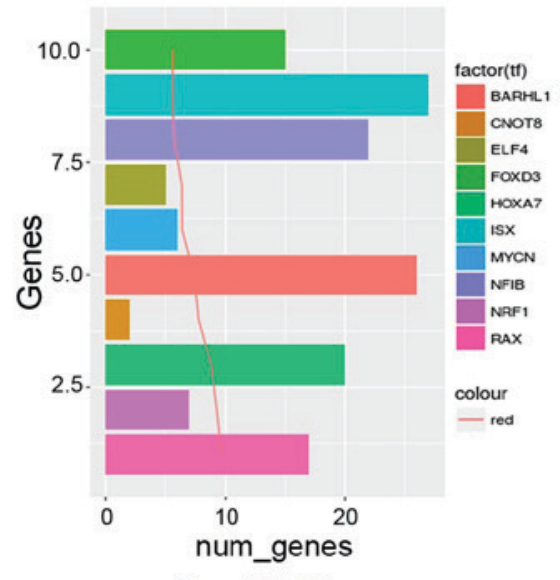

Top 10 TFs

Figure 2. Enrichment of gene quantity distribution. (A) Enriched TF target genes at day 1, 3 and 7, respectively. A small number of transcription factors are enriched in the number of target genes, while most of the transcription factors are not abundant in abundance. Thus, those transcription factors rich in genes may be the focus of our attention. (B) Enriched the top $10 \mathrm{TFs}$, which are located on the left of panel A, are the focus of research. (C) Venn diagram for the enriched TF target gene in DEG at day 1,3 and 7, respectively.

and $\mathrm{P}<0.05$, a total of 300 differentially expressed genes were obtained. Furthermore, the 1st, 3rd and 7th day of the first 10 differences in gene $\log \mathrm{FC}$ charts are shown in Fig. 1A. The relative venn diagrams are shown in Fig. 1B. In this step, the DEG had no TFs, we continued to obtain the influential TFs through following the calculation.

Acquisition of TF genes from enrichment results. In the gene number distribution charts as shown in Fig. 2A, on the 1st, 3rd and 7th day, a small number of TFs enriched most target genes, while the majority TFs were not abundant. It indicated our attention should focus on the TFs which enriched most target gene TFs. We also analyzed the first 10 TFs, as shown in Fig. 2B, TCF12 had 39 genes on the 1st day. MNX1 had 24 genes on the 3rd day and ISX factor had 27 genes on the 7 th day. The target genes for these genes are abundant in differential genes. However, the presence of a large number of target genes may also be more commonly caused by genes regulated by these TFs, such as TFs associated with cell cycle regulation. Therefore, an in-depth analysis of these TFs to 

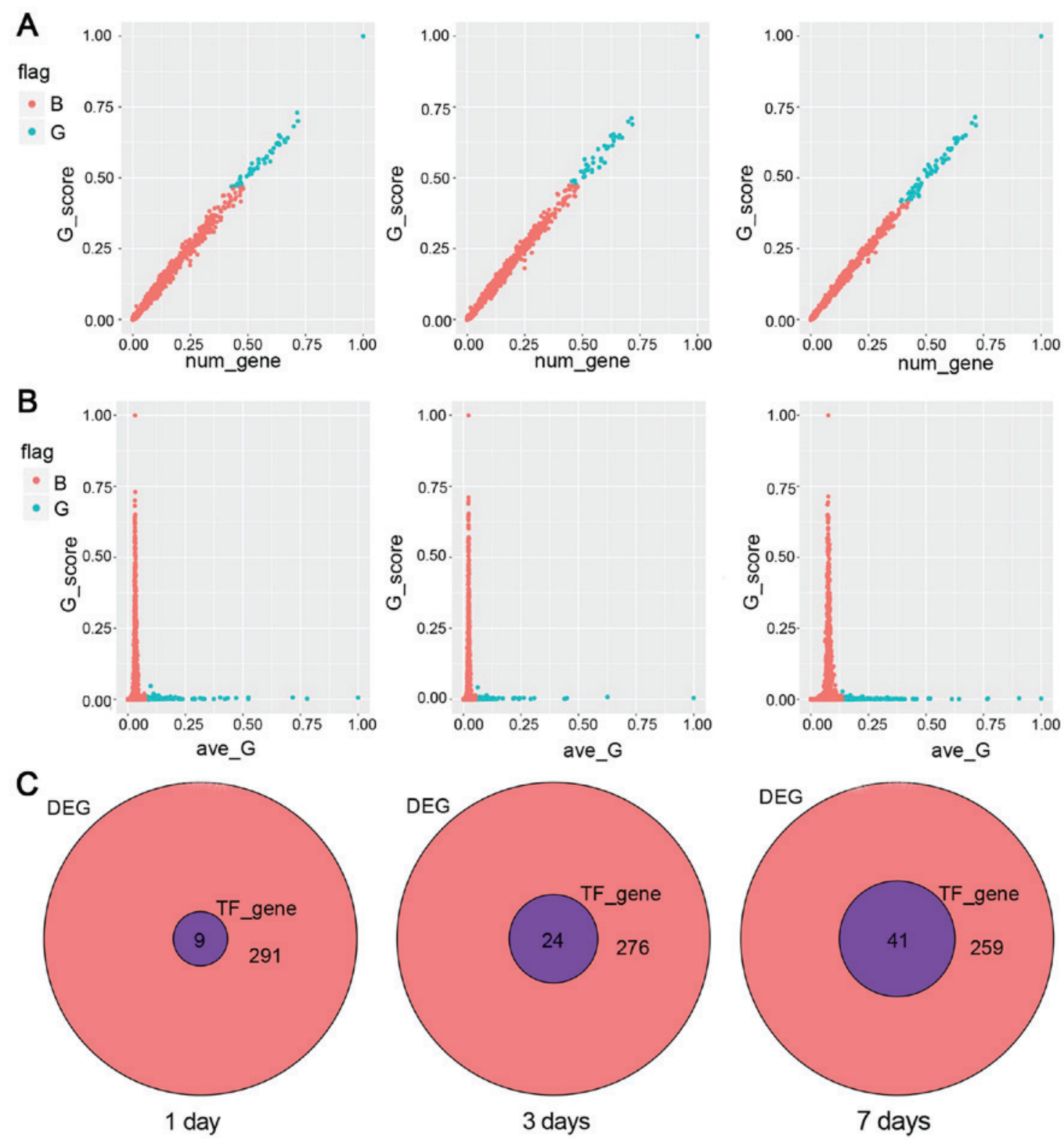

Figure 3. The relationship between $\mathrm{G}$ value and the affected genes at day 1, 3 and 7, respectively. (A) The relationship between $\mathrm{G}$ score and genes number. The red points indicate the rank value is $<0.5$, while the blue points indicate the rank value is $>0.5$. (B) The relationship between $\mathrm{G}$ score and average $\mathrm{G}$. The red points indicate the average of transcription factors below the overall mean plus standard deviation. The blue points indicate the average of transcription factors above the overall mean plus standard deviation. We should focus on the middle area. (C) Target genes of the TF with top G in the expression profile in DEG.
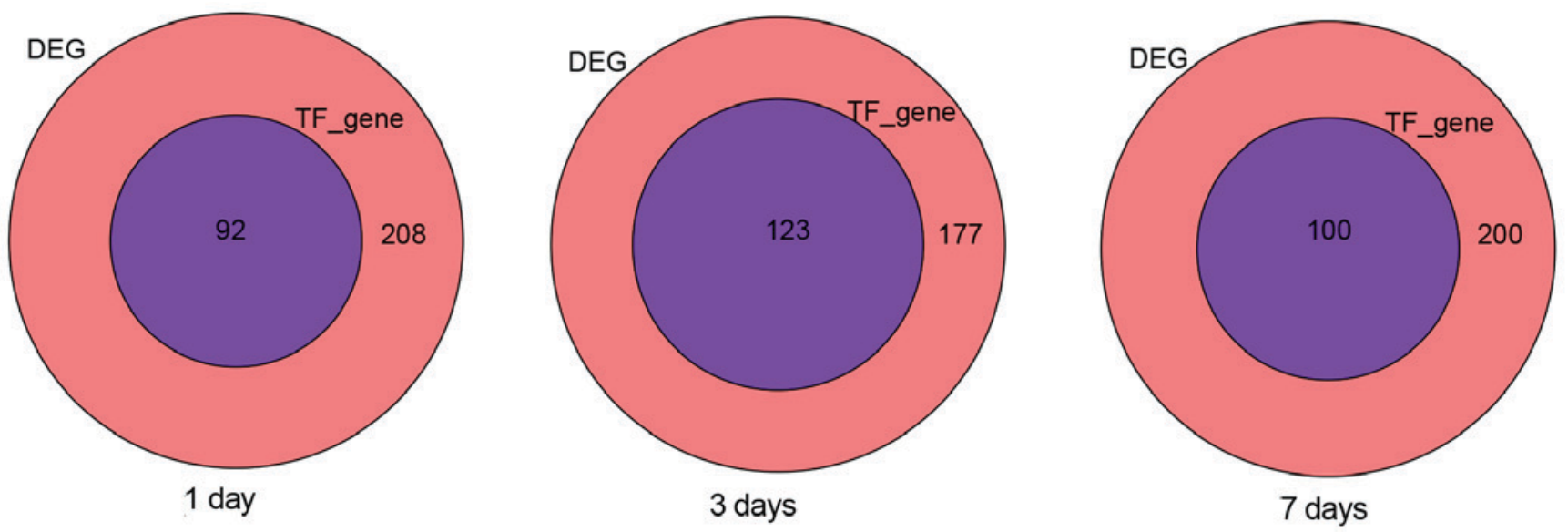

Figure 4. Target genes of the TF with top G in the network in DEG at day 1, 3 and 7, respectively. 

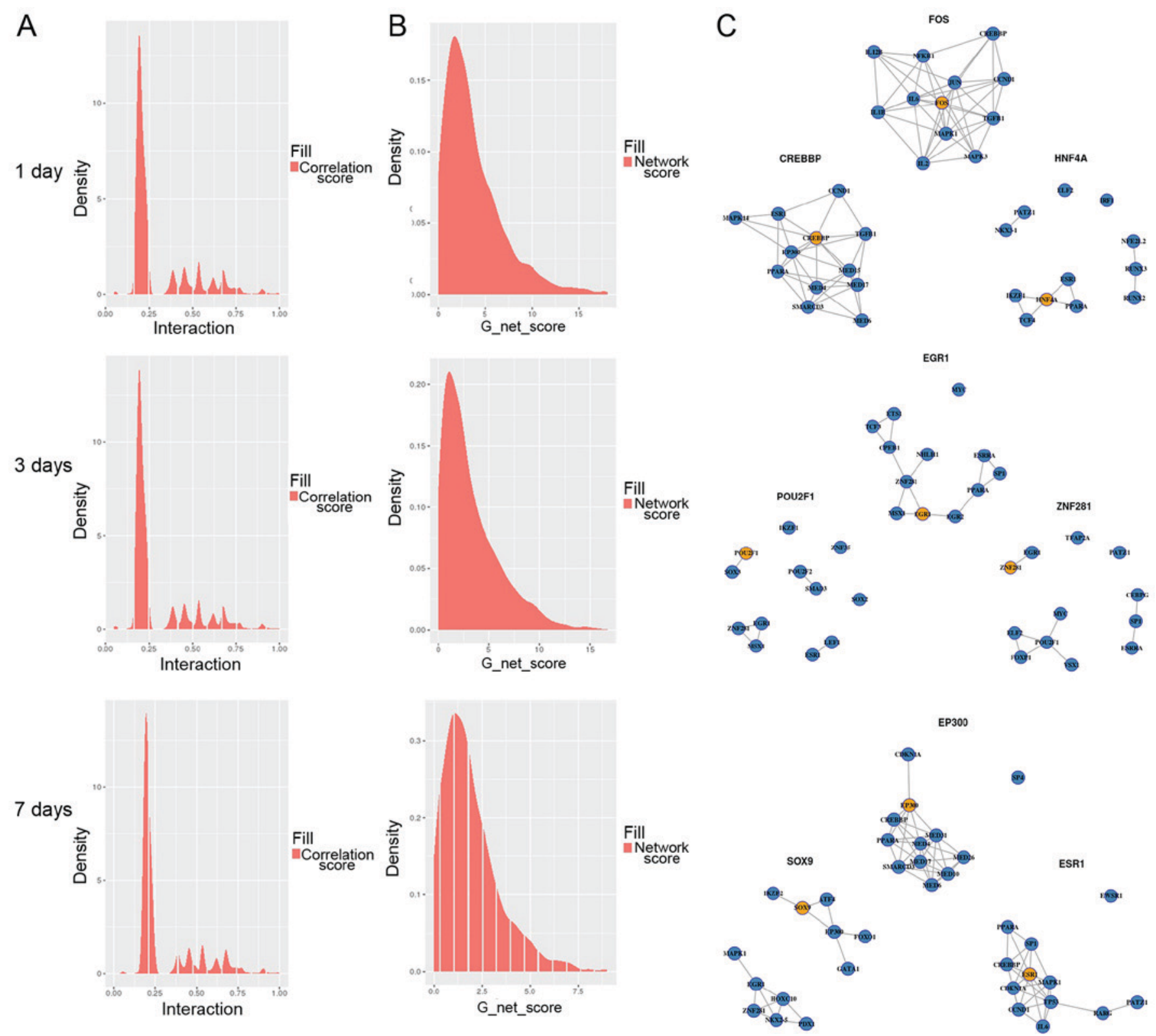

Figure 5. Distribution of PPI final network edge value at day 1, 3 and 7, respectively. (A) G values were not evenly distributed, and most of the transcription factors have a low G-score. (B) The density of edge values mostly converges in the middle. Therefore, attention should be paid to those having a higher value, that is, the figure on the right side of the collection. (C) Network diagram of the maximum network access $\mathrm{G}$ value. The orange dots indicate the transcription factors and the blue dots are the regulatory genes.

find the most affecting TF is more critical in the disease state. Moreover, if these top 10 TFs affect most of the differential genes, it is likely that these TFs are keys to regulation. Finally, we merged the TFs from the DEGs and enrichment analysis. On the 1st day, TFs were JUN, MSX2, TCF12, LEF1, RAX, PAX5, BARHL1, PRRX2, BARHL2, OTX. On the 3rd day, TFs were MEN1, JUN, HOPX, NRF1, MNX1, ARID3A, HDX, CREM, RBPJ, PPARD. On the 7th day, TFs were RAX, NRF1, HOXA7, CNOT8, BARHL1, MYCN, ELF4, NFIB, ISX, FOXD3. The relative venn diagrams are shown in Fig. 2C, in total 80, 58, 66 transcription factor genes were obtained by enrichment analysis on the 1st, 3rd and 7th day, respectively. These results suggest that the transcription factors rich in genes may be the focus of further research attention.
Determination of the direct influence value of TFs. First, we analyzed the relationship between the value of $\mathrm{G}$ and the effects of genes. In general, the influence of TFs would go up with the increase of the number of regulated genes. Furthermore, attention was paid to the TFs which the influence were deviated from the trajectory. As shown in Fig. 3A, blue points represent points $<0.5$. Second, we observed the relationship between the influence ability and the average G score. Generally, TFs with more influence had smaller average value, while the average value of large TFs was usually gathered in the smaller G value. As shown in Fig. 3B, blue dots indicated the average of TFs above the overall mean \pm SD \% . Simultaneously, we judged the influence ability of TFs and observed the top 10 TFs. We found that they could affect most of the DEGs. On the 1st day, the top 10 TFs were 

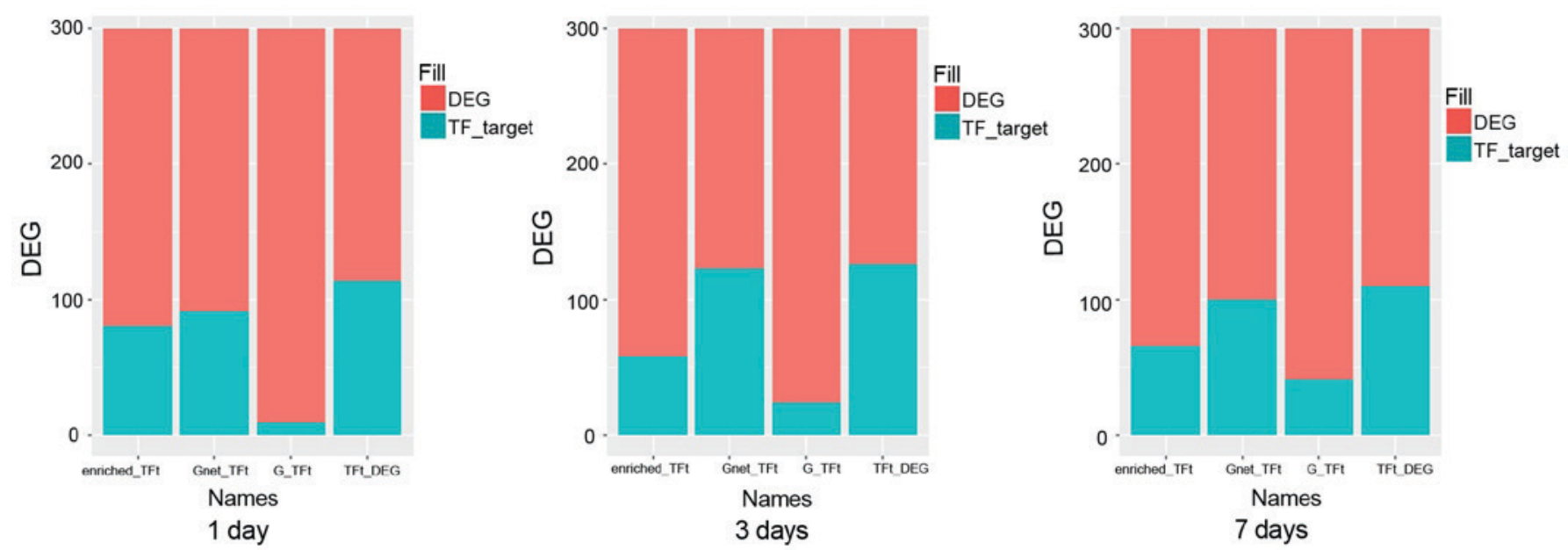

Figure 6. Transcription factor coverage. Red represents DEGs not regulated by TFs, and blue represents DEGs regulated by TFs.

Table III. The best genotypes 'TFall' group on day 1.

\begin{tabular}{clclcl}
\hline Rank & Gene & Rank & Gene & Rank & Gene \\
\hline 1 & JUN & 11 & SP1 & 21 & FOS \\
2 & MSX2 & 12 & HMGN1 & 22 & CREBBP \\
3 & TCF12 & 13 & SLA2 & 23 & HNF4A \\
4 & LEF1 & 14 & HOPX & 24 & IRF1 \\
5 & RAX & 15 & NCOA6 & 25 & ESR1 \\
6 & PAX5 & 16 & MTA3 & 26 & SOX9 \\
7 & BARHL1 & 17 & HF1H3B & 27 & EP300 \\
8 & PRRX2 & 18 & CITED2 & 28 & TRF9 \\
9 & BARHL2 & 19 & EGR & 29 & FOXO4 \\
10 & OTX & 20 & FLI1 & 30 & MEIS1 \\
\hline
\end{tabular}

Table IV. The best genotypes 'TFall' group on day 3.

\begin{tabular}{rlclcl}
\hline Rank & Gene & Rank & Gene & Rank & Gene \\
\hline 1 & MEN1 & 11 & SP1 & 21 & POU2F1 \\
2 & JUN & 12 & NPAS1 & 22 & ZNF281 \\
3 & HOPX & 13 & HF1H3B & 23 & ESR1 \\
4 & NRF1 & 14 & FLI1 & 24 & PPARA \\
5 & MNX1 & 15 & EGR & 25 & MYC \\
6 & ARID3A & 16 & HMGN1 & 26 & FOS \\
7 & HDX & 17 & ZNF529 & 27 & SOX9 \\
8 & CREM & 18 & PAX4 & 28 & EP300 \\
9 & RBPJ & 19 & SP3 & & \\
10 & PPARD & 20 & EGR1 & & \\
\hline
\end{tabular}

SP1, HMGN1, SLA2, HOPX, NCOA6, MTA3, HF1H3B, CITED2, EGR, FLI1. On the 3rd day, the top 10 TFs were SP1, NPAS1, HOPX, HF1H3B, FLI1, EGR, HMGN1, ZNF529, PAX4, SP3. On the 7th day, the top 10 TFs were SP1, HMGN1, HOPX, PLEK2, TOB1, ANKRD22, SLA2, NCOA6, CTBP1, HF1H3B. The relative venn diagrams are shown in Fig. 3C. In total 9, 24, 41 TF genes were obtained by using direct influence value method.

Determination of the network indirect influence value of TFs. This local network was limited to a maximum of three edges. The effect node at each edge was further reduced from the seed TFs, which were located and depended on the extent of its parental prominence. Through the above formula analysis, as shown in Fig. 4, on the 1st, 3rd and 7th day, we obtained $92,123,100$ target genes by using the indirect impact value method.

Determination of PPI final network edge value. The PPI gave us information on the distribution of the network edge value. As shown in Fig. 5A, the density of border values was mostly converged in the middle area, and the set of co-expressive, right-hand sides of the graphs were important for us. In the $\mathrm{G}$ network score distribution (Fig. 5B), G values were not evenly distributed, and most of the TFs had low $\mathrm{G}$ network scores. In general, those well-behaved TFs need to be screened. In Fig. 5C, the network graph of the three TFs for the highest network pathway $\mathrm{G}$ value from the 1st, 3rd and 7 th day are shown. The orange dot indicates the TFs, and the blue dots are the regulatory genes. On the 1st day, the top 10 TFs were FOS, CREBBP, HNF4A, IRF1, ESR1, SOX9, EP300, IRF9, FOXO4, MEIS1. On the 3rd day, the top 10 TFs were EGR1, POU2F1, ZNF281, ESR1, PPARA, MYC, SP1, FOS, SOX9, EP300. On the 7th day, the top 10 TFs were EP300, SOX9, ESR1, EGR1, CREBBP, FOXJ3, IKZF2, FOS, NR3C1, ZNF281.

The coverage of TFs. In general, TFs should cover most DEGs. As shown in Fig. 6, we analyzed the various results to obtain the TF genes and finally obtained the best combination. The enriched-TFt represents TF-related differential genes that are screened by enrichment. The Gnet-TFt represents TF-related differential genes that are screened by indirect impact value. The G-TFt represents TF-related differential genes that are screened by direct impact value. The TFt-DEG represents TF-related differential genes that are screened by the above three methods. The first 10 combinations of the best genotypes 
Table V. The best genotypes 'TFall' group on day 7 .

\begin{aligned} \hline Rank & Gene & Rank & \multicolumn{1}{c}{ Gene } & Rank & Gene \\ \hline 1 & RAX & 11 & SP1 & 21 & EP300 \\ 2 & NRF1 & 12 & HMGN1 & 22 & SOX9 \\ 3 & HOXA7 & 13 & HOPX & 23 & ESR1 \\ 4 & CNOT8 & 14 & PLEK2 & 24 & EGR1 \\ 5 & BARHL1 & 15 & TOB1 & 25 & CREBBP \\ 6 & MYCN & 16 & ANKRD22 & 26 & FOXJ3 \\ 7 & ELF4 & 17 & SLA2 & 27 & IKZF2 \\ 8 & NFIB & 18 & NCOA6 & 28 & FOS \\ 9 & ISX & 19 & CTBP1 & 29 & NR3C1 \\ 10 & FOXD3 & 20 & HF1H3B & 30 & ZNF281 \end{aligned}

obtained for each method were the 'TFall' group, which are shown in Tables III-V in detail (days 1, 3, 7, respectively).

\section{Discussion}

The osteogenesis ability is influenced by a multitude of factors including genetic, metabolic, and physical inputs to coordinate an appropriate adaptive response (11). In this study, we focused on the ability of hMSCs toward osteoblastic lineage in order to add information on the function of osteogenesis ability. On the whole, we obtained the TFs in four different ways, and got the top 10 transcriptional factor combinations with the highest coverage through the Venn diagram. We found that TFs FOS, SOX9, EP300 were commonly expressed in 3 different days in the osteogenic lineages and presented in the PPI network at relatively high degrees. Moreover, TFs CREBBP, ESR1, EGR1 also presented high effects on the 1st and 3rd or 7th day. The above indicated these TFs might have indispensable effects in the mechanisms of osteogenesis process.

Previous findings have suggested that FOS is cellular proto-oncogene product belonging to the immediate early gene family of TFs (12). Furthermore, clear evidence have indicated that the expression of FOS increased during osteogenic differentiation of undifferentiated hMSCs (5), and its mechanism had a relationship with the upregulated transcription of a diverse range of genes involved in cell proliferation, and differentiation $(13,14)$. SOX9, another pivotal TF in osteogenesis, has been shown to have a positive role of delaying osteogenic differentiation in rat adipose stem cells (15). Loebel et al (16) indicated that SOX9 downregulation was required for direct osteogenesis of hMSCs. In their research, the SOX9 protein signal was apparently reduced in DEX-stimulated cells compared with hMSCs in the control medium. In our study, compared with the normal group, the experimental group of SOX9 showed significant differences on days 1, 3 and 7, which also confirmed our prediction was accurate. In addition, EP300 ranked highly among the predicted genes and has been reported to function as an important regulator of cell differentiation. Hu et al (17) reported the inhibition of EP300 expression resulted in a downregulation of total Runx2 and acetylated Runx 2 protein levels in prOB cells as compared to the control group. It is known that Runx 2 plays an important role in the synthesis of type I collagen in bone matrix (18). This phenomenon showed that inhibition of osteoblast differentiation could be achieved by reducing EP300 expression, indicating that Ep300 expression played a positive effect in osteogenic capacity.

In our final prognosis system, we obtained a combination of the optimal combinatorial TFs, in other words, all the important TFs associated with osteogenesis were covered in our system. In our study, although some of the TFs did not appear in the optimal combination, they were all shown to be involved on days 1, 3 and 7 and remained important in osteogenesis. For instance, RUN family including RUNX1, RUNX2 and RUNX3, regulated a variety of genes and played an important role in osteogenesis. Among them, RUNX1 has an essential effect on definitive hematopoiesis $(19,20)$; RUNX2 plays an important role in osteoblast differentiation and bone formation $(21,22)$; RUNX3 has specific effects on certain neurons $(23,24)$, and all of them make a significant contribution to osteoblast capacity.

Through four different ways, we compared the osteoblast data to the control group on days 1,3 and 7, to finally find the combination of the optimal and important TFs. These identified key TFs give a deeper understanding of the molecular mechanism of osteogenic differentiation of hMSCs. TFs FOS, SOX9 and EP300 might exert significant parts in the development osteogenesis, which may provide a reference method for the prediction, diagnosis and prognosis of clinical osteoporosis.

\section{Acknowledgements}

Not applicable.

\section{Funding}

No funding was received.

\section{Availability of data and materials}

The datasets used and/or analyzed during the current study are available from the corresponding author on reasonable request.

\section{Authors' contributions}

XK conceived the study and drafted the manuscript. YS acquired the data. YS and ZZ analyzed the data and revised the manuscript. All authors read and approved the final manuscript.

\section{Ethics approval and consent to participate}

Not applicable.

\section{Patient consent for publication}

Not applicable.

\section{Competing interests}

The authors declare that they have no competing interests. 


\section{References}

1. Fontenot HB and Harris AL: Pharmacologic management of osteoporosis. J Obstet Gynecol Neonatal Nurs 43: 236-245, quiz E20-E21, 2014.

2. Cosman F, de Beur SJ, LeBoff MS, Lewiecki EM, Tanner B, Randall S and Lindsay R: Erratum to: Clinician's guide to prevention and treatment of osteoporosis. Osteoporos Int 26: 2045-2047, 2015.

3. Caplan AI: Review: mesenchymal stem cells: cell-based reconstructive therapy in orthopedics. Tissue Eng 11: 1198-1211, 2005.

4. Augello A and De Bari C: The regulation of differentiation in mesenchymal stem cells. Hum Gene Ther 21: 1226-1238, 2010.

5. Kanis JA, Burlet N, Cooper C, Delmas PD, Reginster JY, Borgstrom F and Rizzoli R; European Society for Clinical and Economic Aspects of Osteoporosis and Osteoarthritis (ESCEO): European guidance for the diagnosis and management of osteoporosis in postmenopausal women. Osteoporos Int 19: 399-428, 2008.

6. Watanabe $\mathrm{K}$ and Ikeda K: Osteocytes in normal physiology and osteoporosis. Clin Rev Bone Miner Metab 8: 224-232, 2010.

7. Harada H, Tagashira S, Fujiwara M, Ogawa S, Katsumata T, Yamaguchi A, Komori T and Nakatsuka M: Cbfal isoforms exert functional differences in osteoblast differentiation. J Biol Chem 274: 6972-6978, 1999.

8. Hanai J, Chen LF, Kanno T, Ohtani-Fujita N, Kim WY, Guo WH, Imamura T, Ishidou Y, Fukuchi M, Shi MJ, et al: Interaction and functional cooperation of PEBP2/CBF with Smads. Synergistic induction of the immunoglobulin germline Calpha promoter. J Biol Chem 274: 31577-31582, 1999.

9. López-Giménez MR and García Gómez JJ: The Fisher's test. Med Clin (Barc) 101: 156-157, 1993 (In Spanish).

10. Stojanova D, Ceci M, Malerba D and Dzeroski S: Using PPI network autocorrelation in hierarchical multi-label classification trees for gene function prediction. BMC Bioinformatics 14: 285, 2013.

11. Luu YK, Capilla E, Rosen CJ, Gilsanz V, Pessin JE, Judex S and Rubin CT: Mechanical stimulation of mesenchymal stem cell proliferation and differentiation promotes osteogenesis while preventing dietary-induced obesity. J Bone Miner Res 24: 50-61, 2009.

12. Sun D, Junger WG, Yuan C, Zhang W, Bao Y, Qin D, Wang C, Tan L, Qi B, Zhu D, et al: Shockwaves induce osteogenic differentiation of human mesenchymal stem cells through ATP release and activation of P2X7 receptors. Stem Cells 31: 1170-1180, 2013

13. Hess J, Angel P and Schorpp-Kistner M: AP-1 subunits: Quarrel and harmony among siblings. J Cell Sci 117: 5965-5973, 2004.
14. Pham DN, Luo H and Wu J: Reduced Ran expression in Ran(+/-) fibroblasts increases cytokine-stimulated nuclear abundance of the AP-1 subunits c-Fos and c-Jun. FEBS Lett 584: 4623-4626, 2010.

15. Stöckl S, Göttl C, Grifka J and Grässel S: Sox9 modulates proliferation and expression of osteogenic markers of adipose-derived stem cells (ASC). Cell Physiol Biochem 31: 703-717, 2013.

16. Loebel C, Czekanska EM, Bruderer M, Salzmann G, Alini M and Stoddart MJ: In vitro osteogenic potential of human mesenchymal stem cells is predicted by Runx2/Sox9 ratio. Tissue Eng Part A 21: 115-123, 2015.

17. Hu Z, Wang Y, Sun Z, Wang H, Zhou H, Zhang L, Zhang S and Cao X: miRNA-132-3p inhibits osteoblast differentiation by targeting Ep300 in simulated microgravity. Sci Rep 5: 18655, 2015.

18. Wei J, Shimazu J, Makinistoglu MP, Maurizi A, Kajimura D, Zong H, Takarada T, Lezaki T, Pessin JE, Hinoi E, et al: Glucose uptake and Runx 2 synergize to orchestrate osteoblast differentiation and bone formation. Cell 161: 1576-1591, 2015.

19. Okuda T, van Deursen J, Hiebert SW, Grosveld G and Downing JR: AML1, the target of multiple chromosomal translocations in human leukemia, is essential for normal fetal liver hematopoiesis. Cell 84: 321-330, 1996.

20. Soung do Y, Kalinowski J, Baniwal SK, Jacome-Galarza CE, Frenkel B, Lorenzo J and Drissi H: Runx1-mediated regulation of osteoclast differentiation and function. Mol Endocrinol 28: 546-553, 2014.

21. Saito T, Ohba S, Yano F, Seto I, Yonehara Y, Takato T and Ogasawara T: Runx1 and Runx3 are downstream effectors of Nanog in promoting osteogenic differentiation of the mouse mesenchymal cell line C3H10T1/2. Cell Reprogram 17: 227-234, 2015.

22. Pan H, Li X, Wang J, Zhang K, Yang H, Li Z, Zheng Z and Liu H. LIM mineralization protein-1 enhances bone morphogenetic protein-2-mediated osteogenesis through activation of ERK1/2 MAPK pathway and upregulation of Runx 2 transactivity. J Bone Miner Res 30: 1523-1535, 2015.

23. Bauer O, Sharir A, Kimura A, Hantisteanu S, Takeda S and Groner Y: Loss of osteoblast Runx3 produces severe congenital osteopenia. Mol Cell Biol 35: 1097-1109, 2015.

24. Wigner NA, Soung Y, Einhorn TA, Drissi H and Gerstenfeld LC: Functional role of Runx3 in the regulation of aggrecan expression during cartilage development. J Cell Physiol 228: 2232-2242, 2013.

This work is licensed under a Creative Commons Attribution-NonCommercial-NoDerivatives 4.0 International (CC BY-NC-ND 4.0) License. 